\title{
Occupational asthma in an electronics factory: a case control study to evaluate aetiological factors
}

\author{
P SHERWOOD BURGE, W H PERKS, I M O'BRIEN, A BURGE, R HAWKINS, D BROWN, \\ AND M GREEN
}

From the Brompton Hospital, London SW3 6HP, UK

\begin{abstract}
This is the final part of a study carried out to investigate occupational asthma due to sensitivity to colophony fumes (a component of soldering flux) in an electronics factory. Fifty-eight workers with occupational asthma employed on the main shop floor were investigated. In them the interval between first exposure and sensitisation varied widely with a group becoming sensitive within one to two years of first exposure, and another group whose sensitisation was delayed for three to 23 years. Once sensitised the interval between arriving at work and the onset of daily symptoms seemed to be bimodally distributed, resembling the immediate and late asthmatic symptoms seen on provocation testing. Twenty-three out of 58 had no definite daily deterioration at work but improved at the weekends. Wheeze and breathlessness occurred in the evenings at home in most, and one-third were woken by breathlessness at least on some nights. These 58 cases were compared with 48 controls without occupational asthma who had worked on the same shop floor for at least four years. Mean levels of $\mathrm{FEV}_{1}$ were significantly worse in the cases before exposure on Monday morning. The cases also had more than twice as much sickness absence as controls. FEV 1 fell by more than $10 \%$ over a working shift in $33 \%$ of cases and $5 \%$ of controls. Atopy (a positive skin prick test to one or more common allergens) and a past history of allergic disease were weakly but significantly associated with being a case. The effects of smoking and a family history of allergic disease were trivial. Prick testing with an antigen derived from the colophony in the solder flux was completely negative, but cases and controls had significantly raised levels of total IgM compared with blood bank controls, perhaps suggesting some previously unrecognised immunological process.
\end{abstract}

This is the final part of a survey of an electronics factory assembling printed circuit boards, subassemblies, and chassis for domestic audio equipment by mass production techniques. Twenty-three workers from this factory have been investigated with occupational type bronchial provocation testing (Burge et al, 1978). All those who stated that they had wheeze or breathlessness better at the weekend have had positive challenges when exposed to flux-cored solder, and to colophony alone (the main constituent of electronic soldering flux). The factory intermittently employs a few workers dipping polyurethane-coated wires into molten solder (tinning). This process liberates fumes of toluene di-isocyanate. So far none of the workers that we have seen from this factory has been sensitive to the fumes of toluene diisocyanate, although we have found workers sensi- tive to these fumes in other electronics factories. The factory is in a modern industrial estate and employed 914 workers and managers at the time of the first survey, which was a prevalence study of symptoms and lung function. Of the workers on the shop floor, $22 \%$ had work-related wheeze or $\sigma$ breathlessness, or both, but work-related symptoms N were uncommon in the other workers (Burge et $a l, 1979)$. The second survey was an analysis of the records of the last 1339 workers leaving the factory for all reasons. This showed that about 20 workers had left for health reasons each year for the past four years, and that 21 workers had specifically stated that they were leaving because of work-related respiratory disease. As these statements were recorded before respiratory disease due to the soldering fluxes was recognised these figures are likely to be underestimates of 
the true incidence of disease. The records also showed that the solderers left for health reasons at least twice as often as other shop floor workers, and at least four times as often as office workers. In addition, workers leaving for health reasons did so after a longer period of employment than workers leaving for other reasons, suggesting that the high labour turnover protected most workers from developing respiratory disease (Perks et al, 1979).

The third survey reported here has derived all its workers from the main shop floor of factory 1 , $91 \%$ of whom were contacted in the first survey (Burge et al, 1979). Our objectives were to relate the respiratory symptoms of the cases to their work exposure, and to answer the following questions:

(1) Are there easily identifiable features in a worker that favour the development of workrelated respiratory symptoms? The role of smoking, personal and family history of allergic diseases, and the results of skin prick testing to common allergens has been evaluated.

(2) Is there a fall in $\mathrm{FEV}_{1}$ over a working shift in symptomatic workers?

(3) Are the high total levels of serum IgM seen in sensitive workers investigated in hospital a feature of sensitisation or exposure?

\section{Methods}

Six groups all working on the shop floor of factory 1 were studied, derived from the first prevalence study. They were all complete groups selected only by their answers to the first questionnaire. The three control groups also had to have been exposed to solder flux fumes at work for at least four years (the mean interval between exposure and onset of symptoms in patients studied in hospital). The groups were as follows:

\section{Controls}

(1) No cough, sputum, wheeze, breathlessness, rhinitis, or eye irritation (23 respondents).

(2) As (1), except cough or sputum or both were present (14).

(3) As (1) or (2), except eye irritation at work was also present (11).

\section{Cases}

(4) All had wheezing that was better at the weekend, and were not taking bronchodilators, sodium cromoglycate, or steroids. They may or may not have breathlessness, cough, sputum, rhinitis, eye irritation, or recurrent chest illness (30).

(5) As (4) except they were taking (during the past 12 months) bronchodilators, sodium cromoglycate, or steroids (13).

(6) All had breathlessness (MRC grade 2 or more) that was better at the weekend (15). None had wheeze which was better at the weekend and none was taking bronchodilators, sodium cromoglycate, or steroids.

These 106 workers completed a further questionnaire with a trained interviewer. They had skin prick tests, venepuncture, and serial measurements of lung function before, during, and after three working shifts. Those making the observations were unaware of the group the worker came from.

The questionnaire included a full work history with particular emphasis on exposure to solderflux fumes, from which the number of years of exposure was calculated. The date of onset of cough, breathlessness, chest tightness, or wheeze was recorded. Symptomatic workers were asked if their respiratory symptoms occurred in the evening at home, ever woke them from sleep, occurred on Saturdays or Sundays when away from work, or were worse, the same, or better on Mondays than Fridays. The interval between coming to work in the morning and the onset of symptoms was recorded. Workers with chest symptoms were also asked whether rhinitis or eye irritation preceded the onset of respiratory symptoms. They were all asked about exposure to solder-flux fumes at home.

Two experienced operators assessed the atopic state by skin prick testing. Antigens used were Dermatophagoides pteronyssinus, grass pollen, tree pollen, Aspergillus fumigatus, and cat dander (all Bencard antigens), and a control solution (phenol saline and glycerine). We also used a solution of abietic acid, which was prepared by mixing commercial grade abietic acid (Sigma) in saline and adding $0 \cdot 1 \mathrm{M}$ sodium hydroxide until dissolved. The solution was titrated back to $\mathrm{pH} 7.5$ with hydrochloric acid, to give a final concentration of $12 \mathrm{mg} / \mathrm{ml}$. Reactions were read at 10-15 minutes. A positive reaction was one in which the weal was at least $2 \mathrm{~mm}$ in diameter with a completely negative control. Those with negative prick tests were classified as non-atopic, those with one or more positive reactions as atopic; three dermatographic workers were excluded from the calculation of atopic rates.

Total levels of serum IgG, IgA, and IgM were measured by the single radial immunodiffusion method. Agarose plates were used with antisera from Dako Patts laboratories. WHO standard sera were used containing $102 \mathrm{IU} / \mathrm{ml}$. All measurements were done in duplicate and the 
mean value taken. Total IgE was measured by the sepharose particle radioimmunosorbant test using anti-IgE (Behring) and a WHO IgE standard. The laboratories did not know from which group the sera came.

FEV 1 and FVC were measured before entering the shop floor in the morning, during the lunch break, and before leaving. Starting times were from 0730 to 0900 and the last recordings were made between 1530 and 1630. Measurements were made (on dry wedge spirometers, Vitalograph, Buckingham, England) during the summer on a Friday, the following Monday, and the following Friday, with the worker standing. Recordings were continued until there were at least two satisfactory traces with the best $F E V_{1}$ and FVC within 0.21 of each other. The best values were recorded. Each worker used the same spirometer on each occasion. Measurements were read on the ATPS scale $\left(20^{\circ} \mathrm{C}\right)$ but not corrected for ambient temperature. The spirometers were calibrated and checked for leaks daily. The mean variation in calibration at 6 litres within each spirometer was $2.4 \%$ and between spirometers was $+4.8 \%$ SEM $0.28 \%$.

Predictive factors separating cases from controls were determined by calculating partial correlation coefficients. For this the following scales were used:

\section{Smoking}

0 Lifelong non-smoker

1 Ex-smoker, stopped before exposure to solderflux

2 Ex-smoker, gave up more than two years ago

3 Smoker of 10 cigarettes a day or less (within past two years)

4 Smoker of 11-20 cigarettes a day (within past two years)

5 Smoker of 21-40 cigarettes a day (within past two years)

6 Smokers of 41 or more cigarettes a day (within past two years)

Pipe and cigar smokers are included in category 4.

Personal history of allergy

0 None

1 Hay fever or eczema before work exposure

2 Hay fever and eczema before work exposure

3 Asthma alone before work exposure

4 Asthma and hay fever or ecezma before work exposure

5 Asthma, hay fever, and eczema before work exposure

Family history of allergy

For each first-degree relative (parents, siblings, and children) the following were scored:
1 Eczema

2 Hay fever

3 Asthma

The total was added and divided by the number of first-degree relatives to obtain a percentage.

Atopic state (the abietic acid test was excluded for this)

0 No positive prick tests

1 One positive prick test

2 Two positive prick tests

3 Three positive prick tests

4 Four positive prick tests

5 Five positive prick tests

The following information was obtained from the employment records of each worker:

(1) Days off a year-excluding training and holidays but including certified and uncertified sickness and absence for no known reason.

(2) The number of mcdical certificates submitted a year and the diagnosis on each. The diagnosis was classified as respiratory (upper or lower) and non-respiratory.

(3) Length of employment.

\section{Results}

Table 1 shows the main details of the controls and cases. The controls were generally older and had longer exposures than the cases because the controls were selected only if they had been exposed to solder-flux fumes for at least four years. This eliminated workers who were likely to develop symptoms but had not done so because their occupational exposure had been short. Overall, $64 \%$ of the cases were current or ex-smokers compared with $46 \%$ of the controls. There were also more cases with a personal history of hay fever, eczema, and asthma in childhood. There were significantly more atopic cases than controls. A greater proportion of the controls had never soldered during their employment. The cases contain more workers who had moved from a soldering job to one without soldering.

Table 2 shows the details of the histories in the affected workers. The severity of symptoms was equivalent in those with work-related breathlessness and wheeze without specific treatment. Those who had work-related wheeze and were taking treatment had more severe symptoms. Wheeze and breathlessness vere common in the evening at home, and about one-third woke at night, on some occasions with breathlessness. More than half had symptoms persisting, but improved, over the weekend. About one-quarter had worsening symptoms throughout the working week so that 
Table 1 Details of the six survey groups

\begin{tabular}{|c|c|c|c|c|c|c|c|c|}
\hline & \multicolumn{4}{|l|}{ Controls } & \multicolumn{4}{|l|}{ Cases } \\
\hline & $\begin{array}{l}\text { No } \\
\text { symptoms }\end{array}$ & $\begin{array}{l}\text { Cough } \\
\text { only }\end{array}$ & $\begin{array}{l}\text { Eye } \\
\text { irritation }\end{array}$ & $\begin{array}{l}\text { Total } \\
\text { controls }\end{array}$ & Breathless & Wheeze & $\begin{array}{l}\text { Wheeze } \\
\text { and } \\
\text { treatment }\end{array}$ & $\begin{array}{l}\text { Total } \\
\text { cases }\end{array}$ \\
\hline Total & 23 & 14 & 11 & 48 & 15 & 30 & 13 & 58 \\
\hline Men & 2 & 1 & 2 & 5 & 2 & 2 & 2 & 6 \\
\hline Women & 21 & 13 & 9 & 43 & 13 & 28 & 11 & 52 \\
\hline Age & $48 \cdot 6$ & $45 \cdot 1$ & $48 \cdot 1$ & $46 \cdot 5$ & 39.9 & $36 \cdot 6$ & $45 \cdot 2$ & $39 \cdot 4$ \\
\hline Mean \pm ISD & 9.9 & $12 \cdot 1$ & $7 \cdot 7$ & 10.9 & $10 \cdot 0$ & $12 \cdot 5$ & $7 \cdot 9$ & $11 \cdot 4$ \\
\hline Length of employment & $10 \cdot 1$ & $10 \cdot 4$ & $8 \cdot 4$ & $9 \cdot 8$ & $6 \cdot 5$ & $6 \cdot 1$ & $8 \cdot 2$ & $6 \cdot 7$ \\
\hline Mean \pm ISD years & $\pm 4 \cdot 3$ & \pm 4.6 & \pm 4.9 & \pm 4.4 & $\pm 4 \cdot 8$ & $\pm 5 \cdot 1$ & $\pm 5 \cdot 3$ & $\pm 5 \cdot 1$ \\
\hline \multicolumn{9}{|l|}{ Current job } \\
\hline Solderer/tinner $\%$ & 22 & 36 & 18 & 25 & 33 & 30 & 38 & 33 \\
\hline Ex-solderer or tinner $\%$ & 13 & 14 & 9 & $12 \cdot 5$ & 33 & 33 & 54 & 38 \\
\hline Never soldered & 65 & 50 & 73 & $62 \cdot 5$ & 33 & 37 & 8 & 29 \\
\hline$\%$ smokers or ex-smokers & 48 & 64 & 18 & 46 & 60 & 77 & 38 & 64 \\
\hline Atopic \% & 9 & 7 & 20 & $12 \cdot 5$ & 20 & 41 & 25 & 40 \\
\hline
\end{tabular}

Table 2 Details of history in affected workers

\begin{tabular}{|c|c|c|c|c|}
\hline & & Breathless & Wheeze & $\begin{array}{l}\text { Wheeze } \\
\text { and } \\
\text { treatment }\end{array}$ \\
\hline Total & & 15 & 30 & 13 \\
\hline $\begin{array}{l}\text { Wheeze/breathlessness in } \\
\text { evening }\end{array}$ & $\%$ & 50 & 57 & 92 \\
\hline $\begin{array}{l}\text { Wheeze/breathlessness } \\
\text { waking from sleep }\end{array}$ & $\%$ & 21 & 33 & 92 \\
\hline Breathless on Saturday & $\%$ & 57 & 47 & 85 \\
\hline Breathless on Sunday & $\%$ & 50 & 47 & 85 \\
\hline $\begin{array}{l}\text { Wheeze/breathlessness } \\
\text { worst on Friday }\end{array}$ & $\%$ & 25 & 25 & 62 \\
\hline $\begin{array}{l}\text { Wheeze/breathlessness same } \\
\text { Monday and Friday }\end{array}$ & $\%$ & 75 & 64 & 38 \\
\hline $\begin{array}{l}\text { Wheeze/breathlessness } \\
\text { worse on Monday }\end{array}$ & $\%$ & $\mathbf{0}$ & 11 & 0 \\
\hline
\end{tabular}

Fridays were their worst days. Only two of 58 patients said they were worst on Mondays, the others being the same on each working day. Figure 1 shows the interval between first exposure and the onset of symptoms; the mean interval was 6.5 years in the group as a whole. There appeared

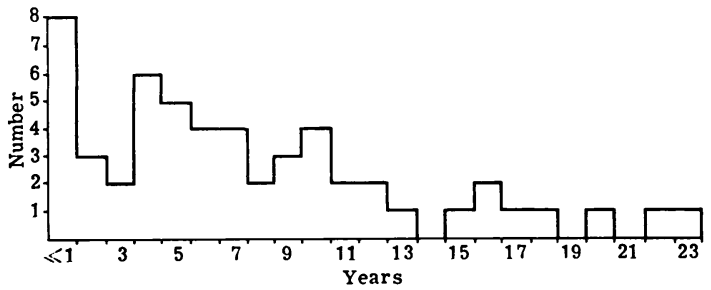

Fig 1 Time at work in years before symptoms developed. to be one group who developed symptoms rapidly and a second group developing symptoms more slowly. Figure 2 shows the interval between coming to work each day and the onset of symptoms in symptomatic workers. There was a bimodal distribution resembling the immediate and late asthmatic reactions seen on provocation testing. However, 23 of 58 had no clear interval, either because their symptoms occurred on occasional days at work, or because recovery did not occur between workdays. Rhinitis occurred before the

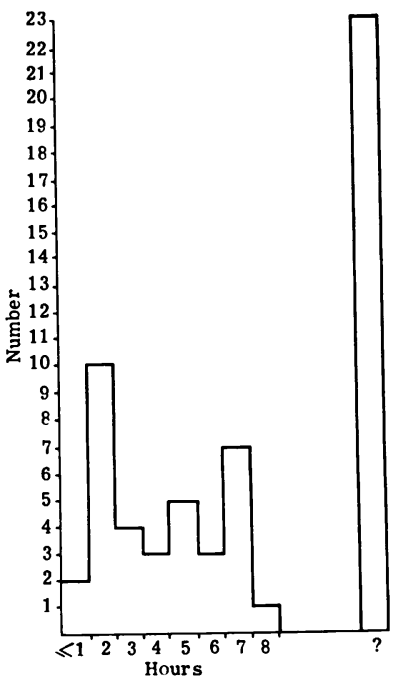

Fig 2 Interval between arrival at work and onset of daily symptoms. 
onset of respiratory symptoms in $48 \%$ of cases and eye irritation before respiratory symptoms in $23 \%$.

Table 3 shows the time lost from work for reasons other than holidays and training. The cases had more than double the number of days off a year than did the controls. Only in those with wheeze on treatment were there significantly more medical certificates mentioning respiratory illness. There were two to five times more sickness certificates mentioning respiratory diseases in the cases than in the controls.

Table 4 shows the results of the total immunoglobulin results analysed by a one way analysis of variance. The three groups of workers with occupational asthma form the factory cases and the three control groups the factory controls. Sera from 30 blood bank donors and 21 administrative staff from a research establishment form an unexposed control group. The mean IgM levels were considerably raised in the factory cases and controls, which did not differ significantly from each other. The values were twice those seen in the unexposed controls. The IgG levels were significantly higher in the cases than the exposed controls $(\mathrm{P}<0.05$, unpaired $t$ test). The two control groups were not significantly different. IgE levels were significantly lower in factory controls than either of the other two groups $(\mathrm{P}<0 \cdot 01)$.

Table 5 shows the results of FEV $_{1}$ and FVC on arrival at work on a Monday morning after a weekend without exposure. This shows that the control had levels very close to predicted but that the cases had a significantly reduced $\mathrm{FEV}_{1}$ and a tendency to a reduced FVC. Those taking treatment had worse values than the other two groups

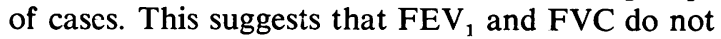
return to normal after a weekend away from work. A fall in $\mathrm{FEV}_{1}$ above $10 \%$ between coming to work and either the midday reading or the reading on leaving work was seen in 16 of 48 cases with adequate readings and in two of 43 controls. Cases taking treatment showed greater and more

Table 3 Time lost from work. Mean $\pm S E M$

\begin{tabular}{|c|c|c|c|c|c|c|}
\hline & \multicolumn{3}{|l|}{ Controls } & \multicolumn{3}{|l|}{ Cases } \\
\hline & $\begin{array}{l}\text { No } \\
\text { symptoms }\end{array}$ & $\begin{array}{l}\text { Cough } \\
\text { only }\end{array}$ & $\begin{array}{l}\text { Eye } \\
\text { Irritation }\end{array}$ & Breathless & Wheeze & $\begin{array}{l}\text { Wheeze and } \\
\text { treatment }\end{array}$ \\
\hline Number of subjects & 23 & 14 & 11 & 15 & 30 & 13 \\
\hline Days off (sick)/man a year. Mean +SEM & $\begin{array}{r}10.8 \\
\pm 1.3\end{array}$ & $\begin{array}{r}12.5 \\
\pm 2.4\end{array}$ & $\begin{array}{r}11 \cdot 8 \\
\pm 2 \cdot 2\end{array}$ & $\begin{array}{l}28 \cdot 7 \\
\pm 6\end{array}$ & $\begin{array}{r}21.9 \\
\pm \quad 2.4\end{array}$ & $\begin{array}{r}32 \cdot 7 \\
\pm \quad 4 \cdot 2\end{array}$ \\
\hline No of respiratory certificates/man/year & $\begin{array}{ll} & 0.2 \\
+ & 0.04\end{array}$ & $\begin{array}{r}0.46 \\
\pm 0.13\end{array}$ & $\begin{array}{r}0.33 \\
\pm 0.13\end{array}$ & $\begin{array}{ll} & 0.6 \\
+ & 0.15\end{array}$ & $\begin{array}{ll} & 0.66 \\
\pm & 0.1\end{array}$ & $\begin{array}{r}2.5 \\
\pm 0.3\end{array}$ \\
\hline No of non-respiratory certificates/man/year & $\begin{array}{r}0.54 \\
\pm 0.13\end{array}$ & $\begin{array}{r}0.62 \\
\pm 0.18\end{array}$ & $\begin{array}{ll} & 0.38 \\
\pm & 0.1\end{array}$ & $\begin{array}{r}2.5 \\
\pm 0.7\end{array}$ & $\begin{array}{r}1.5 \\
\pm 0.3\end{array}$ & $\begin{array}{r}1.6 \\
\pm 0.7\end{array}$ \\
\hline
\end{tabular}

Table 4 Immunoglobulin levels in workers with occupational asthma, factory controls, and unexposed controls (blood bank donors and administrators in a research establishment). Mean values $\pm S E M$

\begin{tabular}{|c|c|c|c|c|c|c|}
\hline & $\begin{array}{l}\text { Unexposed } \\
\text { controls } \\
\text { (a) }\end{array}$ & $\begin{array}{l}\text { Factory } \\
\text { controls } \\
\text { (b) }\end{array}$ & $\begin{array}{l}\text { Factory } \\
\text { cases } \\
\text { (c) }\end{array}$ & $\begin{array}{l}\text { Analysis of variance for } \\
\text { difference between } 3 \text { groups } \\
\text { (P value) }\end{array}$ & $\begin{array}{l}\text { Differe } \\
\text { groups } \\
\text { T test }\end{array}$ & $\begin{array}{l}\text { en pairs of } \\
\text { P values }\end{array}$ \\
\hline $\begin{array}{c}\text { Number: Women } \\
\text { Men } \\
\text { Total }\end{array}$ & $\begin{array}{l}33 \\
18 \\
51\end{array}$ & $\begin{array}{r}43 \\
5 \\
48\end{array}$ & $\begin{array}{r}50 \\
6 \\
56\end{array}$ & & & \\
\hline Total IgG IU/ml & $\begin{array}{r}112 \\
\pm \quad 4 \cdot 3\end{array}$ & $\begin{array}{r}125 \\
\pm \quad 6.0\end{array}$ & $\begin{array}{r}142 \\
\pm \quad 5.6\end{array}$ & $<0.001$ & $\begin{array}{l}a-b \\
a-c \\
b-c\end{array}$ & $\begin{array}{l}<0.1 \\
<0.001 \\
<0.05\end{array}$ \\
\hline Total IgA IU/ml & $\begin{array}{r}101 \\
\pm \quad 6.5\end{array}$ & $\begin{array}{r}137 \\
\pm \quad 8.5\end{array}$ & $\begin{array}{r}123 \\
\pm \quad 8.9\end{array}$ & $<0.01$ & $\begin{array}{l}a-b \\
a-c \\
b-c\end{array}$ & $\begin{array}{l}<0.002 \\
<0.05 \\
\text { NS }\end{array}$ \\
\hline Total IgM men IU/ml & $\begin{array}{c}101 \\
\pm 11 \cdot 1\end{array}$ & $\begin{array}{r}239 \\
+\quad 44 \cdot 8\end{array}$ & $\begin{array}{c}223 \\
\pm 40 \cdot 2\end{array}$ & $<0.001$ & $\begin{array}{l}a-b \\
a-c \\
b-c\end{array}$ & $\begin{array}{l}<0.001 \\
<0.001 \\
<0.2\end{array}$ \\
\hline Total IgM women IU/ml & $\begin{array}{c}132 \\
\pm \quad 11 \cdot 7\end{array}$ & $\begin{array}{c}252 \\
\pm \quad 13.6\end{array}$ & $\begin{array}{r}284 \\
\pm \quad 17.9\end{array}$ & $<0.001$ & $\begin{array}{l}a-b \\
a-c \\
b-c\end{array}$ & $\begin{array}{l}<0.001 \\
<0.001 \\
\text { NS }\end{array}$ \\
\hline $\log _{10}$ total IgE IU/ml & $\begin{array}{ll} & 1.7 \\
+\quad & 0.09\end{array}$ & $\begin{array}{r}1.27 \\
\pm \quad 0.09\end{array}$ & $\begin{array}{r}1.8 \\
\pm \quad 0.1\end{array}$ & $<0.001$ & $\begin{array}{l}a-b \\
a-c \\
b-c\end{array}$ & $\begin{array}{l}<0.002 \\
\text { NS } \\
<0.001\end{array}$ \\
\hline
\end{tabular}


Table 5 Lung function in cases and controls (Monday before work)

\begin{tabular}{|c|c|c|c|c|c|c|}
\hline & \multicolumn{3}{|l|}{ Controls } & \multicolumn{3}{|l|}{ Cases } \\
\hline & $\begin{array}{l}\text { No of } \\
\text { symptoms }\end{array}$ & $\begin{array}{l}\text { Cough } \\
\text { only }\end{array}$ & $\begin{array}{l}\text { Eye } \\
\text { irritation }\end{array}$ & Breathless & Wheeze & $\begin{array}{l}\text { Wheeze and } \\
\text { treatment }\end{array}$ \\
\hline $\begin{array}{l}\text { FEV }_{1} \% \text { predicted. } \\
\text { Mean } \pm \text { SEM }\end{array}$ & $\begin{array}{c}100 \\
\pm \quad 3.5\end{array}$ & $\begin{array}{r}96 \\
\pm \quad 3.6\end{array}$ & $\begin{array}{r}100 \\
\pm \quad 5.5\end{array}$ & $\begin{array}{l}90 \\
\pm \quad 3.0\end{array}$ & $\begin{array}{r}93 \\
\pm 2 \cdot 5\end{array}$ & $\begin{array}{r}82 \\
\pm 4 \cdot 5\end{array}$ \\
\hline $\begin{array}{l}\text { FVC } \% \text { predicted. } \\
\text { Mean } \pm \text { SEM }\end{array}$ & $\begin{array}{r}102 \\
\pm \quad 3 \cdot 2\end{array}$ & $\begin{array}{r}98 \\
\pm 3 \cdot 2\end{array}$ & $\begin{array}{r}103 \\
\pm \quad 5.9\end{array}$ & $\begin{aligned} & 95 \\
\pm & 2 \cdot 4\end{aligned}$ & $\begin{array}{r}98 \\
\pm 2.4\end{array}$ & $\begin{array}{r}94 \\
\pm \quad 4 \cdot 4\end{array}$ \\
\hline $\begin{array}{l}\text { FEV }_{1} \text { fall by } \geqslant 10 \% \text { during } \\
\text { shift }-\% \text { total }\end{array}$ & 5 & 8 & 0 & 38 & 17 & 58 \\
\hline
\end{tabular}

consistent falls in $\mathrm{FEV}_{1}$ than in those not taking treatment, again suggesting that these form a more severely affected group. Nine of the cases have had bronchial provocation testing in hospital with significant falls in $\mathrm{FEV}_{1}$ after exposure to solder-flux fumes. Of these nine, only four showed a greater than $10 \%$ fall in $\mathrm{FEV}_{1}$ in the course of a day at work.

Table 6 shows the results of a multiple regression analysis of predictive factors separating cases from controls. The effects of smoking and family history of allergic disease is small and statistically insignificant. Atopy and a previous history of allergic disease are both significantly more common in cases than controls. When all these factors are combined only $17 \%$ of the difference between cases and controls is statistically "explained."

Table 6 Partial correlation coefficients $(r)$ for predictive factors comparing cases with controls

\begin{tabular}{llll}
\hline & $r$ & $r^{2}$ & $P$ \\
\hline Smoking & 0.167 & 0.028 & NS \\
Personal allergic history & 0.257 & 0.066 & $<0.02$ \\
Family allergic history & 0.026 & 0.0007 & NS \\
Atopic state & 0.278 & 0.077 & $<0.01$ \\
Total & & 0.172 & \\
\hline
\end{tabular}

\section{Discussion}

In this case control survey we set out to compare the most normal of the workers with longer than four years' employment with the most severely affected workers still employed to maximise any difference between the groups. There were very few asymptomatic workers so those with cough and sputum, but without breathlessness, were included as controls. The next most normal group were those who complained of eye irritation at work, but again were not breathless or wheezy. This last group may have represented an early affected group. They had normal lung function, however, and were similar in most respects (apart from smoking and being more atopic) to the other control groups. Only $23 \%$ of the cases said that they had eye irritation starting before the onset of wheeze or breathlessness, although nearly all the cases now complained of eye irritation at work.

The symptoms in affected workers were very similar in type to those we have investigated in hospital. Many had symptoms in the evening at home, and a third were woken from sleep by breathlessness on bad nights. This group was selected because symptoms improved at the weekend. More than half, however, still complained of wheeze or breathlessness at the weekend. The more severely affected tended to get progressively worse through the working week so that Fridays were their worst days. The mean interval between first exposure to solder-flux fumes and the onset of symptoms was 6.5 years in this group, although the longest period was 23 years. There have been no new materials added to the soldering fluxes in this time, so this is likely to represent the true time taken for sensitivity to develop.

We thought that we were less likely to find falls in $\mathrm{FEV}_{1}$ in symptomatic workers who were taking treatment than those who were not. We also thought we were more likely to measure a fall in $\mathrm{FEV}_{1}$ in those who complained of wheeze rather than in those whose only complaint was breathlessness. Because of this we omitted workers with breathlessness, better at the weekend, who were taking treatment as we were unable to cope with the measurement of lung function in a larger group. In retrospect this group was probably the most severely affected, and should have been included. Those taking treatment appeared to be a more severely affected group, and although falls in $\mathrm{FEV}_{1}$ were likely to be minimised, those taking treatment showed the greatest falls during the working day.

Measurement of lung function before and at the end of a working shift is a poor method of 
recording the extent of bronchospasm in occupational asthma. The diurnal variation seen in classical asthma also occurs in occupational asthma. The lowest readings of $\mathrm{FEV}_{1}$ usually occur on waking in the morning and may take at least two hours to resolve. This results in a low initial reading on arrival at work. There is then an increase in $\mathrm{FEV}_{1}$ unless the work factors have an immediate effect. The onset of work-related wheeze in this study was usually within four hours. In some, however, the onset was after leaving work. In many of our patients who have kept records of peak flow the readings are lowest in the evening after leaving work. These factors lead to small differences in $\mathrm{FEV}_{1}$ between the beginning and end of a shift, compared to the severity of their symptoms.

Some workers have symptoms on occasional days only. Failure of extraction fans and closing of windows in the winter and during rain were common precipitating factors. This survey took place in very hot summer weather when ventilation was at its best, minimising their occasional attacks.

We were able to record a fall in $\mathrm{FEV}_{1}$ of $10 \%$ or more over a workshift in 16 of 48 cases and two of 43 controls with satisfactory recordings. Most of the other cases probably had real occupational asthma, which we failed to record as only four of nine challenge positive workers in this study had a $10 \%$ fall in FEV $_{1}$.

A final factor minimising the change in $\mathrm{FEV}_{1}$ in this series was our failure to correct all readings for ambient temperature and pressure. The greatest temperature change we recorded was $10^{\circ} \mathrm{C}$ between the first reading and the midday reading. This difference would over-estimate the midday reading by about $4 \%$ compared with the initial reading. We were unable to correct the readings as each series of readings were spread over $1 \frac{1}{2}$ hours, and we did not take frequent enough temperature readings to make the correction reliable. This problem was compounded by the very hot weather and the absence of ventilation in the place where lung function was measured.

The cases had two to three times as much time off work as the controls. Most doctors' diagnoses on the certificates did not mention a respiratory disease. It is quite understandable that a new cause of occupational asthma fails to appear on certificates, but it is hard to explain why respiratory causes were not more prominent. We did not ask specific questions about other symptoms, but the workers we have seen in hospital have had few other complaints apart from headache and in two cases muscle aches, fever, and weight loss, implying a systemic reaction.

This case control survey has derived its subjects from current workers surveyed in a prevalence study (Burge et al, 1979) and so the cases are to some extent a survivor population as well as the controls. It was designed to detect personal factors that might be important in the development of cccupational asthma. Thirty-one percent of the cases were atopic. This approximates to the proportion seen in a general adult population. Only $10 \%$ of the controls were atopic, suggesting that the others had left. Atopy was the most significant factor found to be associated with being a case, but on the current evidence the association shown here is not strong enough to make the exclusion of atopics worth while. A past history of allergic disease was also significantly associated with being a case. The effects of smoking and a family history of allergies were trivial. Our failure to show easily recognised personal factors to be strongly associated with becoming a case suggests that worker selection is unlikely to reduce materially the incidence of occupational asthma in this factory. A cohort study, however, would provide a better estimate of the excess risk of atopy and a past history of allergic disease. Our previous findings of a diminishing incidence of disease between the solderers, other shop floor workers, and office workers suggests that the degree and duration of exposure are the most important factors in the development of occupational asthma.

Provocation testing has shown that colophony fume is the main sensitising agent in workers from this factory (Burge et al, 1978). Colophony is the residue after turpentine has been distilled from pine resin, and consists largely of abietic and pimaric type resin acids, the exact composition depending on the source (Yoye and Lawrence, 1967). This factory uses fluxes incorporating Portuguese $\mathrm{Y}$ and American WW colophony. We have attempted to develop a skin test to help in diagnosing occupational asthma due to colophony. ? Our preparation of abietic acid produced negative results, probably because the resin acids work as haptens. It is also possible that decomposition $\omega$ products of the colophony produced on heating (Drugov and Murav'eva, 1976) are responsible for $\stackrel{\varrho}{\subset}$ the sensitisation. Colophony itself, however, is a potent skin sensitiser, showing that it is capable? of eliciting an immunological response.

Raised total IgMs were a surprising finding in $\stackrel{\vec{D}}{\vec{D}}$ workers investigated in hospital. This study has $\frac{?}{\mathbb{D}}$ shown that the exposed controls had greatly $\varrho$ raised levels compared with blood bank controls, ? the cases only having slightly higher values. IgM 8 
was the only antibody not significantly raised compared with blood bank controls in a group of asthmatic patients (BTTA, 1975). The raised IgM levels in these workers may imply that so far unknown immunological mechanisms are involved in workers exposed to colophony fumes.

We would like to thank $\mathbf{R}$ Bello, C Burge, $\mathbf{J}$ Collins, D Cramer, G Edge, M Graham, W Hanmer, E I'Anson, D Jones, J Mitchell, A Morris, I Petheram, M Phillips, and J Wooden, whose enthusiasm made this survey possible.

\section{References}

British Thoracic \& Tuberculosis Association (1975). Immunological features of asthma (part II). Clinical Allergy, 5, 403-416.

Burge, P S, Harris, M G, O'Brien, I M, and Pepys, J (1978). Respiratory disease in workers exposed to solder-flux fumes containing colophony (pine resin). Clinical Allergy, 8, 1-14.

Burge, P S, Perks, W H, O'Brien, I M, Hawkins, R, and Green, $M$ (1979). Occupational asthma in an electronics factory. Thorax, 34, 13-18.

Drugov, Y S, and Murav'eva, G V (1976). Gaschromatographic analysis of air contaminated by rosin degredation products. Zhurnal Analiticheskoi Khimii, 31, 2205-2211.

Perks, W H, Burge, P S, Rehahn, M, and Green, M (1979). Work-related respiratory disease in employees leaving an electronics factory. Thorax, 34, 19-22.

Yoye, N M, and Lawrence, R V (1967). Resin acid composition of pine oleoresin. Journal of Chemical and Engineering Data, 12, 279-282.

Requests for reprints to: Dr P S Burge, Brompton Hospital, London SW3 6HP.

\section{BOHS Fifth International Symposium on Inhaled Particles}

\section{8-12 September 1980}

The Fifth International Symposium organised by the British Occupational Hygiene Society will be held in the City Hall, Cardiff, Wales. It continues the series of symposia held at five-yearly intervals, the first in Oxford in 1960 and since then in Cambridge, London, and Edinburgh. The aim will again be to provide a forum for the presentation and discussion of the results of recent research concerning the entry of particles into the body via the respiratory system, their disposal, and the ensuing biological reactions. Emphasis will be on basic mechanisms and quantitative dose/response relationships.

The symposium is being organised in association with the Commission of the European Communities.

Requests for further information should be sent to: Mr D A Phillips, Joint Organising Secretary, MRC Pneumoconiosis Unit, Llandough Hospital, Penarth, Glamorgan CF6 1XW, UK. 